\title{
Students' Mornigness and Afternoonness and Their Use of ICT to Develop Their English Skill
}

\author{
Siti Asmiyah \\ English Language Education Department \\ UIN Sunan Ampel \\ Surabaya, Indonesia \\ siti.asmiyah@uinsby.ac.id \\ Nadiya Dwiki Isnin Safitri \\ English Language Education Department \\ UIN Sunan Ampel \\ Surabaya, Indonesia \\ nadiyaelfangel@gmail.com
}

\author{
Josephine Nabilla Putri \\ English Language Education Department \\ UIN Sunan Ampel \\ Surabaya, Indonesia \\ josephinabilla@gmail.com \\ Mohammad Annas Miftakhuddin \\ English Language Education Department \\ UIN Sunan Ampel \\ Surabaya, Indonesia \\ annasmifta@gmail.com
}

\author{
Ariyanto, S.Pd \\ MTsN 2 Kota Surabaya \\ Surabaya, Indonesia \\ iyan83665@gmail.com
}

\begin{abstract}
There are many learning styles in English Language Teaching. If we could mention some of the learning styles, there are two learning style that can be seen by the time of students' learning time which are students that study better in the morning while others in the afternoon. These different learning styles may influence their performance in English skill, including their use of ICT to facilitate their learning. This study explores students' morningness and afternooness and their use of ICT to develop their English skills. This study was performed with a quantitative research method. The sample of this study is 90 students class VII until IX of MTsN 2 Kota Surabaya. The data were collected using questionnaires that will be distributed to 90 students grade VII, VIII, and IX of MTsN 2 Kota Surabaya. The rest of the paper will reveal the findings and possible implication of the research regarding the students' characteristic of their learning style which are a study in the morning and afternoon that influence their performance in English skills also their Use of ICT. Thereby, we can know that students will perform their best to improve their English skill, whether study in the morning or afternoon.
\end{abstract} skill

Keywords : morningness, afternoonness, ICT, English

\section{INTRODUCTION}

In language learning education, the learners come from different background and culture. They have different possibility to master the language. For example in learning
English, there are some students come as a native speaker, they can easily master the language, but for another student who does not come a a native speaker, they will face some difficulties. The difference chance can be considered on the learning strategy that took by the learner to master the language. Some students actually have their own strategy based on their need and their time preferences. Students in education have different learning strategies according to their respective personalities. Their learning styles are also different. We can distinguish them into several parts: cognitive, metacognitive, memory-related, compensatory, affective, and social. In this case, we focus on secondary school students. Students shift their time of day preferences from morningness to afternoonness during the age of puberty. According to Cornet (1983, p.9) learning styles are the general approaches, for example, global or analytic, auditory or visual. These are used by the students in acquiring a new language or in learning other subjects. These styles are the overall designs that give general direction to learning behavior.

Other statements which related to the previous statement is Dunn \& Griggs (1988, p.3), they stated that learning styles is the biologically and developmentally imposed set of the characteristics that make the same teaching method enjoyable for some and terrible for others. Then, based on Scarcella \& Oxford (1992, p.63) Learning strategies are defined as "specific actions, behaviours, steps, or techniques such as seeking out conversation partners, giving oneself encouragement to tackle a difficult language task used by students to enhance their own language. When the learner consciously selects strategies that fit his or her learning style and the L2 task, these strategies can be classified into six 
groups. They are cognitive, metacognitive, memory-related, compensatory, affective, and social. Human differs in their time of day preferences. Morning types prefer to wake up and go to bed early and feel at their best moment in the morning. Whereas, afternoonness types prefer later bedtimes and rise times become progressively more alert across the day and feel at their best moment in the evening.

Based on the Bailey and Heitkemper (2001) stated that neither type differs in daily rhythms of physiological variables, for example hormones secretion, body temperature, heart rate, and blood pressure. In relation to this because we know that every students has their own learning styles or learning strategy to develop their English skills, definitely they have their own way to perform their best to reach their goals at learning. There are so many way to improve their ability in learning language especially English, also everyone can have a good mark too but not all students can perform their best all the time in a day. They also have a time when they feel not good to do something and when they feel absolutely good to do something. Additionally, students shift their time of day preferences from morningness to afternoonness during the age of puberty. So that's why they cannot perform their best in a particular time and vice versa. Furthermore, human differ in their time of day preferences. Morning types or morningness type prefer to wake up and go to bed early and feel at their best moment in the morning. Whereas, afternoonness types prefer later bedtimes and rise times become progressively more alert across the day and feel at their best moment in the evening.

Based on rationale above biologically their have their own time when they really feel their best and when they feel exhausted. As a result, to reach their goals in learning English or to develop their English skills they need a good condition of their body. So that they can really focus of what they want to achieve. But not only having a good condition they can also use a media for learning so that it can help them to reach the goals easily. Apart from this, media was created to making students more enjoy and easier to understand the material. Talking about a media in this globalization era when the thing comes modern and getting faster, something that can represent is ICT or information and communication technologies. It is increasingly becoming an essential thing for the human being in doing many purposes, especially in teaching and learning English. In relation to this, it is noted that the utilization of ICT in education has a positive impact on the learning environment, particularly in primary and secondary education (Mikre, 2011).

Based on the theories, we can say that technology has an important role in education to improve the quality of teaching and learning in the classroom. Technology can also give a positive impact on the learning environment. The previous study conducted by Sophia Fithri Al-Munawwarah (2014) finds that there are three benefits of using ICT in English teaching and learning, which are helping the teachers to conduct interesting and enjoyable learning activities, promoting learner autonomy, and motivating the students to learn. Additionally, as the teachers who are lives in the globalization era, we should have a creative and innovative notion to increase our students' understanding in accepting a lesson in the class and enrich their knowledge in various aspect. Furthermore, it is pointed out that without supplementary materials actually EFL teachers can design learning activities, nevertheless, it is important to bear in mind that much of the richness of language instructions can be designed by using supplementary materials including ICT (Brown, 2001). It also discovered in the previous study that conducted by Mukti Prkash Thapaliyah (2014) the findings discovered that there are plenty of ICT tools were most used by students are audiotape, mobile phone, computer, television, radio, videotape and email. From the previous study, we can see that those kinds of supplementary materials is essential for teaching and learning process in order to help the teacher to designing activity in the class also help the students to understand the material easily.

Based on the theory and the previous study, undoubtedly the role of ICT for developing students in learning English is trusted. On the other hand, using a good media without knowing the limit of the body to work will make the students feel fatigue and it can impact to their performance in learning process. So, as the students they should know about their optimal time to learn. Those background leads the researcher desire to investigate about the students type whether they more morningness or afternoonnes and their use of ICT to develop their English skills. Because when the students in the good condition they can perform their best to learn English so that they can develop their English skills well. Along with this, to increase a good quality of learning process the students need an aid for that. The aid or we can say a media that mostly used by the students is ICT. For this reason, the researcher have three research questions. The first is, whether the type of students are seen from their biological tendencies. The second is what kind of ICT media do students use based on their biological tendency time. For the last research question is how do they use ICT to develop their English skill. Additionally, this research will take a place at MTsN 2 Kota Surabaya and for the subject of this research are the students of VII E, VIII $\mathrm{B}$, and IX A class with the amount total of the students are 90 students. The researcher hope this research can beneficial for the students because they will know their type whether is morningness or afternoonnes and the best ICT media that can they use for developing their English skills.

Information and Communication Technology are defined as "a various set of technological tools and resources that are used for communicating, creating, disseminating, storing, and managing information. These technologies involve computers, the internet, broadcasting technology (radio, television) and cellphone (Singh R, 2013). UNESCO has defined the term ICT as plural, which refers to many technologies and as encompassing term which involves the complete scope of electronic tools by which we gather, record and stores 
information and exchange as well as distribute information to others. ICT comprises many different tools that enable capturing, interpreting, storing and transmitting information in a fast and easy way. Information and Communication Technologies are advances in technologies that offer rich worldwide resources and collaborative environment for research information which are necessary for meaningful educational experience and interactive discussions also training, delivery of particular course lesson or material, and tremendously fruitful for global exchange of ideas (Carmona \& Marin, 2013).

Moreover, ICT is a field of work and study that "includes technologies such as desktop and laptop computers, software, peripherals, and connections to the Internet that are intended to fulfil information processing and communications functions" (Statistics Canada, 2008). Another definition for ICT comes from UNESCO, which claim that ICT is "the combination of informatics technology with other, related technologies, and specifically communication technology" (UNESCO, 2002). Thus, ICT uses the newest technologies to process and communicate information. To conclude, ICT are both software and hardware that can be used for helping people in communicating, creating, disseminating, storing and managing the information in a fast and easy way.

\section{METHOD}

This study has employed quantitative research method. Moreover, this research was conducted in one of the junior high school in Surabaya, namely MTs Negeri II Kota Surabaya. The consideration for choosing the school is because this study needs the school that already implement the ICT in the teaching and learning process. So that the researcher can do the interview and giving questionnaires because this study not only wants to seek a students' morningness and afternoonness but also their use of ICT to develop their English skills. The participants or the subjects are the students in MTs Negeri II Kota Surabaya, especially the students of class VII E, VIII B, and IX A. The participants or the subject are chosen by random sampling.

Furthermore, the researcher uses two kinds of the instrument to collect the data. The first instrument is for the students' morningness, and afternoons, this questionnaire has nineteen questions and validated by sleep health foundation. This instrument can help the user to know what times of the day they are more productive and what times are the best for the user to sleep. The second questionnaire is for the use of ICT to develop the students' English skills; this questionnaire is developed by the researcher it is adopted by Erasmus+ Program: "21st Century European Classroom: meeting the challenge of the digital era with innovation and creativity".

This questionnaire has been developed by the researcher so that it can be suitable for the research. The instruments which were used in this study were aimed to measure the students' type of their preference biological time, whether it's more early bird or night owl. Also, for the students' use of ICT if we look at their preference biological time, whether it is a more early bird or a night owl. Additionally, from the instrument above the researcher will also get data for how the students use ICT to develop the English skills by doing an interview to answer the question how students' use ICT to develop their English skills.

To collect the data, the researcher does an interview and distributing questionnaires. After all of the data were collected, the researcher will analyze the data. For the data from questionnaires, the researcher will analyze it and see whether the students is more early bird or night owl and what kind of ICT that they use to develop their English skills. For the interview data, the researcher will transcript the audio and do coding. The last is for analyzing the whole data. The researcher will use a descriptive qualitative. After all of the data is analyzed, the researcher makes findings and conclusion about the data.

\section{FINDINGS AND DISCUSSION}

In this section, the researchers want to prove students' tendency of their biological time based on the questionnaire and interview that the researchers have been done before.

From the result of the research, we find that every student can wake up in the morning at 5.00-6.30 or less than if they don't have any activity on that day. It caused they want to spend their time in the holiday to do some activity that they can't do in weekdays, it can be seen from the interview transcript " $m y$ reason why I always wake up early in the morning on holidays because I want to do some activities that I can't do in the weekdays like watching a movie, playing game, scrolling social media for hours, and other quality time activities with my family." They will sleep early at 9.00-10.15 if they can do it faster and they don't have any activity to do on that night.

In a daily day, most of them can wake up because they do it their self without any help. The alarm not really help them to wake up in the morning. They said "I usually wake up in the morning because of my own awareness, I rarely using my phone alarm to wake me up because if the alarm ringing I always turn off the alarm and go back to sleep."

They always need to eat their breakfast in the morning before they do the activities on that day. The teenagers in their age do not have behaviour to do some heavy activity like doing sport or anything in a long time. They are just doing sport in a short, they like jogging or swimming in a short time between 1-2 hours per week, because they don't have enough time to do besides their activity in school. From the interview, they said, "I'm not used to doing sport in a long time, the first reason is I don't have enough time to do because I need to finish my homework and study, the second reason is my body is not used to doing sport for a long time because I get tired very easily." 
If in a day they have so many activities to do, they can sleep early between $8.00-9.00$ because they feel so tired and they should do more activity in school the next day. They explained, "If in a day I have so many activities in school and I had studied more, I will sleep early in the night because my body and my brain feel so tired." Then the researchers give them a case: If tomorrow you have a big test for two hours and you need to force yourself to finish it. At what time you want to do the test? And the result is, most of them want to do the test at 8.00-10.00 in the morning meanwhile they can choose to do the test in the afternoon or in the night. This is caused because if they do the test in the morning, then they can do it easier because they still remember well about what they learned before. It can be seen while they do the interview, "If I could choose at what time I have to take the test, then I will take the test in the morning at 8.00-10.00. Because at that time, my brain is still fresh, and I still remember well about what I learned before." The researchers give them the second case: For some reasons, you need to sleep a few hours later than usual, but you don't need to wake early on the next day. From some choices, what are you going to do? And the result is, most of them choose to wake up in the morning as usual and not go back to sleep after it. Because if they have some activities to do in the night and requires them to sleep lately, then they will wake up as usual on the next day to do some activities than continue their sleep, "If I have so many activities to do in in the night and it requires me to sleep lately, then I still wake up in the morning as usual. Because I don't want to waste my time for sleeping for so long, better if I wake up early and waste my time to do some activities or finish my homework or spend my time with my family and my friends."

If they have so many things to do from the night until morning between 4.00-06.00 and they didn't sleep yet at that time, they choose to sleep in the afternoon on the day before they do the activities and keep awake in the night and go back to sleep in the afternoon on the day after they keep awake for so long time. It can be proven from the interview transcript: "If I have so many homework to do or if I have an exam on the next day, I will sleep in the afternoon on the day before I do my work and keep awake in the night to finish my work and go back to sleep in the afternoon on the day after they keep awake for so long time." And in case, if they need to do the hardwork for two hours and you free to plan the day. What is the best time you choose to do? Then most of them choose their best time to perform their hardwork is in the morning between 8.00 - 10.00 A.M because they are still excited to do the hardwork. "if I have to do the hardwork for two hours then I can handle that day, I will choose my best time at 8.00-10.00 A.M in the morning to perform my best. Because if I do the hardwork in the morning, I still excited to do anything and my body is still fresh and strong." It proved that most of the students choose to do the hardwork and doing sport in the morning while their body and their brain are still fresh and strong.
If the students can choose their own time to go to school. What is the best time they choose? Then the result is, most of them choose to go to school in the morning start at 8.00 A.M until five hours later. It can be seen from the interview answer: "if I can choose my best time to go to school, I will go to school at 8.00 A.M in the morning. Because it is not too early and not too late to start the lesson." Then they gave some choices whether they are morningness or afternoonness type, and the result is the best time for them to perform their work is in the morning than in the afternoon. Because in the morning they still excited to do the activity, their body and their brain are still fresh, the other is in the morning is the best time while we can enjoy the fresh air. They explain that the right time to start the activity is in the morning at 5.00 a.m. Then the reasons why they didn't choose to start activities in the afternoon or in the night because at that times they already tired and not enthusiasm to do anything. Then the next section is about the ICT tools used by students based on their biological time and the way how they develop their English skills.

For the listening skills, the students or the subject research prefer to use a software application rather than hardware. It can be seen in the interview transcript most of them said that they do a listening exercise through software, like what the interviewee said in the interview transcript, "I don't know about the hardware for listening, the thing that I know is the software for listening like Google Translate." "Actually I don't like the English lesson, but I like to listen and sing an English song maybe that the way I do a listening exercise. For the application that I use is called Music Match."

From the questionnaire, the researcher can also know that students don't do a listening exercise all the time, they do a listening exercise just sometimes. The researcher also ask the interviewee about how they develop their English skills, and the researcher can see from the interview transcript above, they like to listening music because they don't really like English also typing an English word and then listen to it through Google Translate.

The next is about the speaking skills, the participants prefer to use a hardware application rather than software application like a cellphone. Also, they are rarely doing speaking exercise using ICT they prefer to speak directly for the speaking exercise; that's why they are rarely to use ICT for speaking exercise. It can be seen in the interview transcript, "I rarely use ICT for speaking exercise, I mostly speaking English directly in front of the mirror when I want to exercise my speaking skills."

From the interview transcript above we can see that they are rarely to do a speaking exercise using ICT they prefer to do a speaking exercise directly.

The third is about their reading skills, the participants prefer to use a hardware application to develop their reading skills. Based on the interview and questionnaire, the hardware 
that they use is the cell phone. Through the cell phone, they can read a lot of literature in it, like what the interviewee said in this following interview transcript, "The way I develop my reading skill is through reading a lyric in one of application in my cell phone called Joox. Actually, Joox is an application for listening to music, but it also provides the lyric, so I prefer to read through my cell phone in Joox application because it is fun." "I prefer to open Google and search a story about my idol; it's more fun rather I read a book."

From the interview above, the students prefer to do a reading exercise through a fun way, like reading a story on the internet or reading a lyric while they are listening to music. For the frequency of the use of the ICT itself, based on the questionnaire, they just sometimes do reading exercise.

The following skills are writing skill, the subject research prefer to use software for doing a writing exercise, it can be seen in the result of the questionnaire that the students are more like to use a software application to develop their writing skill. Additionally, the frequency of the use of ICT itself is just sometimes. "To develop my English skill, especially my writing skill, I prefer to use social media to develop my writing skill." "The way I develop my writing skill is to write a story in my Wattpad account because it can help me to develop my writing skill also can express my feelings."

From the interview transcript above the students is more like to use a software application to develop their writing skill and the way they do a writing exercise is from writing on social media or an application for share their story.

To develop the students' vocabulary skills, they prefer to use hardware to enrich their vocabulary. Based on the questionnaire and the interview transcript, the application hardware that they use to develop their vocabulary skill or mastery is the cell phone. To know the way they use ICT to develop their vocabulary, the researcher already does an interview. Based on the interview, the students said to exercise the vocabulary skill they read a lot of literature on the cell phone. "I use a cell phone to develop my vocabulary skill to read a story on the internet." "I read a status that use English as the language to enrich my vocabulary because sometimes reading a book is just boring."

From the statement in the interview above the students prefer using a cell phone as the hardware of application to develop their vocabulary skill or mastery. Finally, the last one is about the students' grammar skill. To develop their grammar skill, they prefer to use the software. Based on the interview that the researcher does, the software that the students mostly use is called Brainly or Ruang Guru. To know how they use it to develop their skill, the researcher does an interview. The result of the interview is they join an online course and then they can learn the grammar from the lesson from the online course. "To develop my grammar skill, I join an online course called Ruang Guru, inside the online course, we will have a lesson about grammar plus the explanation and banks of question about grammar." "I frequently open Brainly.com to find a task or exercise about grammar so that I can learn from that."

From the interview and the questionnaire above the students like to use a software called Ruang Guru or Brainly to develop their grammar skill.

From the result of questionnaire and interview, it is discovered that students of VII E, VIII B, and IX A class are the morningness type it can be seen by their daily life while they start their daily activity, most of their answer in the questionnaire and interview prove that they are included morningness type rather than afternoon type. Moreover, about their preference of ICT use to develop their English skill and the way they use it to improve their English skills.

The first is about the listening skill; they prefer to use software such as google translate and music match to do a listening exercise. They learn in a fun way by listening to music that is using the English language. The second is about speaking skills; they prefer to use hardware rather than software. The hardware that they mean is a cell phone, but they more like to do a speaking exercise by speaking in front of the mirror directly.

For the next skill is reading skill; they prefer to use hardware tools for reading exercise like a cell phone. Because through their cell phone they can read a lot of literature, especially on the internet. The next skill is writing skill, student of VII E, VIII B, and IX A class prefer to choose a software application to improve their English skills through writing on the social media and writing their story on the one of application on the internet.

The next skill is vocabulary; the students prefer to choose hardware to improve their vocabulary mastery or skills. A cell phone is a hardware chosen by the students to read a story or status in social media because sometimes reading a book is boring. The last skill is Grammar; the students prefer to choose software to develop their grammar skill. They choose Ruang Guru and Brainly.com to learn and do their work about grammar.

\section{CONCLUSION}

The researchers can conclude that students of VII E, VIII $\mathrm{B}$, and IX A class prefer to start their work and perform their best in the morning include doing sport, doing a hard examination, and daily activity. One of the daily activity is learning, especially learning English. In this era, students can learn English in every way, whether in a traditional way or modern way. Because we live in a globalization era where the people in this world are following the times where everything is done in a modern way. Back to the way of study, the students who live in the globalization era prefer to use ICT as the tools for learning. 
The ICT itself divides into two types; there are software and hardware which most of the students in VII E, VIII B, and IX A at MTsN 2 Kota Surabaya prefer to use software for listening skill like Youtube and Music Match. Furthermore, for the speaking skill, they prefer to choose hardware for improving their speaking skill, but they also assert that the best way to learn to speak by speaking directly without any tools. In addition, for the reading skill, they prefer to use hardware like cell phone because through cell phone they can read a lot of literature on the internet even some of them are love to reading lyrics in the music player.

For the next skill is writing, most of the students prefer to choose a software application to improve their writing skill such as writing their own story in the one of application like Wattpad. The next is vocabulary skill. The students prefer to use hardware tool to develop their English skill by reading a story on the Internet because they think reading a book is just boring. The hardware its self is a cell phone. The last skill is grammar; most of the students in VII E, VIII B, and IX A class prefer to use software to improve their grammar skill. The online media they usually use are Ruang Guru and Brainly.com.

\section{REFERENCES}

[1] Mikre, F. (2011). The Roles of Information Communication Technologies in Education: Review Article with Emphasis to the Computer and Internet. Ethiopian Journal of Education and Science, 6 (2), 109-126

[2] Brown, H. Douglas. (2001). Teaching by Principle and Interactive Approach to Language Pedagogy. New York: Longman Inc.

[3] Singh, r. (2013). ICT Usage Among Distance Learners and Their Academic Performance: A Multidisciplinary Study. International Journal of Enhanced Research in Educational Development, 1 (7), 7-12

[4] Carmona, MArina Garcia \& Marin, Jose Antonio mArin. (2013). ICT Trends in Education. $1^{\text {st }}$ Annual International Interdisciplinary Conference. AIIC. 24-26 April 2013. Portugal

[5] Statistics Canada. (2008). Information and Communications Technologies (ICTs)

[6] UNESCO. (2002). Information and Communication Technology in Education 